\title{
Human Capital Externalities: Evidence from the Transition Economy of Russia
}

\begin{abstract}
Alexander Muravyev ${ }^{1}$
Abstract

The paper tests for the existence of human capital externalities, more precisely those stemming from higher education, using a micro-level approach: a Mincerian wage regression augmented with average level of education in a local geographical area (city). To solve identification problems arising due to endogeneity of average education the study exploits a natural experiment provided by the process of economic transition in the former communist economies. We argue that the educational structure of cities under central planning was determined by the government rather than the market; thus the average educational attainment in cities at the end of communism can be regarded as exogenous with respect to wages prevailing after the start of transition. The identification strategy based on the use of the pre-transition average education is applied to data from the Russian Longitudinal Monitoring Survey, RLMS. Empirical results are consistent with the presence of significant human capital (educational) externalities in the Russian economy. According to the estimates, one percent increase in the fraction of people with higher education in a city results in the increase of wages of city residents by 1-2 percent. The result proves to be robust to several changes in the empirical specification.
\end{abstract}

JEL classification: I2, J31

Keywords: Human Capital Externalities, Cities, Russia

This version: February 2006

\footnotetext{
${ }^{1}$ Department of Economics, European University Institute, Florence. E-mail: alexander.muravyev@iue.it
} 


\section{Introduction}

Human Capital Theory states that individuals invest in their human capital - by spending money and time on education and training - in order to enhance own productivity which is in turn rewarded by higher wages. Consistent with this supposition is a vast amount of empirical studies demonstrating that the private return to education - an increase of individual's earnings resulting from one additional year of schooling - falls in the range of 6 to $10 \%$ (Card, 1999). The theory asserts that investments in human capital are undertaken by individuals until the point where the marginal productivity gained equals the marginal opportunity cost (from the individual's viewpoint).

Benefits of human capital accumulation ${ }^{2}$ by a person need not pertain to that person solely. An individual's investment in her own human capital may also increase productivity of the other factors of production - physical capital or human capital of others. Importantly, the channels of such influence - the most prominent of which is sharing of knowledge and skills trough formal and informal interaction between people in the same industry, city, region or economy - may not be internalised by individual families or firms which gives rise to human capital externalities. Since Lucas (1988) contribution, the hypothesis on human capital externalities has become a standard modelling tool in the New Growth Theory where they are regarded as a major factor of sustainable growth (Spagat, 2002). ${ }^{3}$

Much of the interest in this area is explained by important policy implications of human capital externalities. This primarily concerns education which is often regarded as a primary means of human capital accumulation. If education has the characteristics of a public good, the private returns to education may underestimate the full returns to society - an increase in total earning resulting from a one-year increase in average schooling. In such case, education is not provided at the efficient scale and public investment in education is desirable.

\footnotetext{
${ }^{2}$ In addition to education and training, human capital accumulation may occur through the learning that experience yields.

${ }^{3}$ Besides static productivity externalities such as those suggested by Lucas, higher stock of human capital may facilitate creation and adoption of new technologies or make learning-by-doing more effective thus leading to dynamic human capital externalities (Venniker, 2000). In addition, there may be other external social impacts, which can in turn have indirect economic effects. The latter include reduction of socially costly activities such as crime as well as benefits arising from enhanced political behaviour (Moretti, 2003).
} 
The existence of educational and, more generally, human capital externalities remains a questionable issue from both theoretical and empirical perspectives. In theory it has been suggested, for example, that education may play a pure signalling role. If education is nothing else but a signal of individual's innate ability, the social returns to education are zero: the aggregate income stays unchanged when all workers increase their schooling by one year.

Empirical evidence remains scarce and inconclusive, as emphasized in several recent surveys (e.g., Moretti, 2003; Psacharopoulos and Patrinos, 2002, Sianesi and Van Reenen 2002; Venniker, 2000). It comes from two types of studies: based on macro- and micro-data. In the empirical macro-economic literature, the stock of human capital is typically used to explain either the long-run level or the long-run growth rate of the economy. The micro approach explores whether, given a worker's educational level (and possibly other characteristics), the worker's wages rise with the average educational level attained in a relevant geographical area, usually a city.

As argued by Krueger and Lindahl (2001), the micro approach is less suitable for uncovering the social returns to education since it defines educational externalities in a limited way. Indeed, education may affect national income in ways that are not fully reflected in wages - through lower crime, reduced welfare dependence, etc. Moreover, the focus on a local geographical area prevents identification of externalities that arise if more skilled workers generate ideas used in other regions of the country. Also, spill-over effects may (partly) accrue to employers instead of workers. In this light, macro-level analysis is a better tool to reveal these wider effects of such investments on economic growth (Sianesi and Van Reenen, 2002). However, compared with the micro analysis the macro approach faces many more methodological problems in interpreting the coefficient on education. These include measurement of human capital over time and across countries, causality issues, mostly ad hoc nature of model specifications and high sensitivity of estimates to the choice of additional regressors (Sianesi and Van Reenen, 2002). Krueger and Lindahl (2001) also point out the fragility of macro-economic evidence that is based on cross-country studies and suggest that a focus on growth across regions of countries with reliable data is more promising.

This paper tests for the existence of human capital externalities - more precisely those stemming from higher education - using the abovementioned micro ap- 
proach and data from a transition country (Russia). From a research perspective, the focus on a transition country may help circumvent a number of methodological problems that complicate identification of human capital externalities in the empirical micro-studies. We exploit the idea that the transition economies offer a unique natural experiment where market forces are imposed on the environment shaped by the central planning mechanism. The basic assumption underlying this paper is that the average educational attainment in the Russian cities at the end of the Soviet time was exogenous with respect to wages prevailing after the start of transition. ${ }^{4}$ From a policy viewpoint, knowing the size of the externalities may be useful in determining the optimal level of public support of education.

This paper is organised as follows. Section 2 focuses on the theoretical foundations and design of the micro-studies and outlines several identification problems typical of such studies. Section 3 summarises the existing empirical evidence. Section 4 explains the plausibility and potential gains from implementing a micro-level study using data from a transition country. Estimation framework and data are described in section 5 followed by empirical analysis in section 6 . Section 7 concludes.

\section{Identification and measurement of human capital externalities in micro-level studies}

\subsection{Basic framework}

The simplest framework that establishes the relationship between individual's earnings and the average stock of human capital in a relevant geographical area comes from a model developed by Lucas (1988). In this model, externalities are built into aggregate production functions in the form of technological increasing returns while the exact mechanism that generates externalities remains uncovered. This model is sketched below to provide a baseline for subsequent discussion. It is built on the following key assumptions: there exists a competitive economy, production takes place in several regions (cities), output is produced by identical agents (which differ only with respect to their human capital) and is traded on the national market rather than locally.

\footnotetext{
${ }^{4}$ A similar empirical strategy to study human capital externalities is employed by Jurajda (2004) who relies on exogeneity of the pre-transition distribution of education across Czech regions.
} 
Let $c$ index cities, $i$ - workers and $L_{c}$ be the number of workers living in a city c. In the simplest model without capital, let $y_{i c}$ be the output (and also the marginal product) of a worker $i$ living in city $c$. Assume that it depends on the stock of human capital the worker possesses $h_{i c}$ and on the city productivity shifter $A_{c}$ so that

$$
y_{i c}=w_{i c}=A_{c} h_{i c},
$$

where $w_{i c}$ denotes earnings of worker $i$. The aggregate production function for a city can be written the following way:

$$
Y_{c}=A_{c} \sum_{i=1}^{L_{c}} h_{i c}
$$

To formalise the idea that interactions among workers raise their productivity, $A_{c}$ is assumed to depend on the aggregate human capital in a relevant city. As in Lucas (1988) model, the aggregate human capital can be measured as the average human capital in the city, $H_{c},=E_{c}\left(h_{i c}\right)$, so that

$$
A_{c}=B_{c} H_{c}^{\alpha}
$$

where $B_{c}$ measures a city-specific effect and human capital externalities are captured in elasticity parameter $\alpha .^{5}$ Worker wage is therefore expressed as

$$
w_{i c}=A_{c} h_{i c}=B_{c} H_{c}^{\alpha} h_{i c} .
$$

By taking logarithms, one transforms the above equation into

$$
\ln w_{i c}=\ln B_{c}+\alpha \ln H_{c}+\ln h_{i c} .
$$

The last equation provides rationale for using a standard Mincerian regression augmented with the average stock of human capital in a relevant city in order to identify human capital externalities.

More recent models draw the existence of externalities from the process of market interactions (e.g., Acemoglu, 1996). In Acemoglu's model an increase of the average education of the workforce raises equilibrium wages due to complementarity between human and physical capital even in the absence of technological or learning externalities. Importantly, the earnings equation resulting from this model is very similar to one obtained from the Lucas model. ${ }^{6}$

\footnotetext{
5 Another possible assumption is that the skills of the most talented individuals create externalities (Murphy, Shleifer and Vishny, 1991).

${ }^{6}$ Analysis of the mechanisms that may generate educational externalities represent a separate issue which lies outside the scope of this paper.
} 


\subsection{Extensions}

An ideal framework for identifying human capital externalities would be a random assignment of different overall levels of human capital across cities, finding identical individuals in the cities and measuring difference in their wages before any sorting occurs. Yet, such experimental framework is not available. The literature on human capital externalities offers several extensions of the basic model that highlight identification problems accompanying empirical analysis. They primarily focus on unobserved heterogeneity of individuals (e.g., innate ability), selective migration and imperfect substitution among workers with different educational attainments (see, e.g., Acemoglu and Angrist, 2000; Moretti, 2002; Ciccone and Peri, 2002). These issues are briefly reviewed below.

Heterogeneous individuals. Let workers be heterogeneous in terms of their unobserved ability with higher ability causing higher earnings. In such case, as argued in the empirical literature on human capital externalities (e.g., Acemoglu and Angrist, 2000; Silva, 2002), estimation may be based on the following model:

$$
\ln w_{i c}=\alpha+\ln B_{c}+\beta_{A} A_{c}+\beta_{S} S_{c}+\gamma_{a} a_{i c}+\gamma_{h} S_{i c}+u_{i c},
$$

where $B_{c}$ is a city fixed effect, $A_{c}$ is the average ability in city $c, S_{c}$ is the average schooling of people living in city $c, a_{i c}$ is ability and $s_{i c}-$ schooling of individual $i$ living in city $\mathrm{c}$.

Ability at the individual and city levels is not observed. This poses no problem in empirical analysis as long as ability does not affect wages or is uncorrelated with schooling and other explanatory variables. If this is not the case, OLS estimate of the parameter of interest, $\beta_{S}$, is generally inconsistent.

Selective migration. Identification problems arising from selective migration are discussed in Acemoglu and Angrist (2000), Moretti (2002) and others. For example, Acemoglu and Angrist (2000) use a simple model to show that positive city-specific shocks to wages attract more educated workers to a city and increase average human capital through migration. This generates positive correlation between average education and wages across cities and may bias OLS estimates.

Similarly, Moretti (2002) argues that unobserved characteristics of cities may be correlated with the share of people with higher educational attainment. Cities with 
particularly high productivity of skilled workers pay higher wages and therefore attract more skilled workforce. In this case the causal relationship runs from high wages to the average level of education of the labour force, rather than the other way around.

Imperfect substitutability of workers with different level of education. If workers with different educational attainment are imperfect substitutes in production (for which there is ample evidence, e.g., Katz and Murphy, 1992) wage changes may capture the complementarity between skilled and unskilled workers. In particular, under imperfect substitutability an increase in the share of educated workers may raise wages of unskilled workers due to the supply effect even in the absence of any externality. In contrast, wage of skilled workers will tend to go down. Hence, the existence of externalities is firmly established only if an increase in average education is related to an increase of wages of more educated workers. Based on this, Moretti (2002) estimates external returns to education separately for each educational group and compares results for high and low education individuals. This approach, while providing evidence on the existence of externalities, hardly says anything about their magnitude, as emphasised in Ciccone and Peri (2002).

\section{Empirical evidence from micro-level studies}

The first study that attempted testing for and measuring of human capital externalities using Mincerian approach is a paper by Rauch (1993). Using cross-sectional analysis of US data from 1980 he found that one year increase in average schooling led to 3$5 \%$ increase in wages. The average level of education in this study was treated as historically predetermined, which evoked much criticism in subsequent analyses.

Using panel data from 1960-1980 Censuses in the US, Acemoglu and Angrist (2000) reported that each additional year of average schooling in a state raised individual wages by $7 \%$ (OLS); however, IV estimation - which was intended to circumvent a bunch of identification problems outlined above, in particular endogeneity of individual and average educational attainment - resulted in coefficients that were small and insignificantly different from zero.

Rudd (2000) tested for the existence of human capital spillovers in the US on the state level with a panel dataset. Using OLS estimation and controlling for state 
fixed effects he finds that the observed correlation between state educational attainment and individual earnings stems from the fact that the average level of education proxies for other, truly productive factors. In other words, the study finds no support for the hypothesis that human capital spillovers affect individual earnings.

Moretti (2002) notes that OLS estimates show a large positive relationship between the share of college graduates in a city and individual wages. He then attempts to control for unobservable individual characteristics and unobservable city-specific shocks that may raise wages and attract people with higher educational attainment to different cities. He finds that a one percentage point increase in the labour force share of college graduates increases the wages of high-school dropouts and college graduates by $1.9 \%$ and $1.6 \%$ respectively while wages of college graduates raise by $0.4 \%$. The result that an increase in the supply of college graduates raises their wages of college graduates is consistent with the presence of human capital externalities.

Ciccone and Peri (2002) find significant positive externalities with magnitudes similar to those in Rauch (1993) and Moretti (2002). However, when imperfect substitutability is allowed for, there is little evidence of positive human capital externalities.

Silva (2002) analysed a sample of displaced workers in Portugal to test for an association between individual earnings and local average education and did not find any convincing evidence of the presence of educational externalities.

The only study of human capital spillovers (to the knowledge of the author) that exploits the "natural experiment" feature of the transition process is a paper by Jurajda (2004) who uses Czech data. The paper assumes exogeneity of the historical location of colleges (which is a typical assumption in the literature) or, given the nature of the central planning system, exogeneity of the pre-transition distribution of human capital across Czech regions in general. No evidence of increasing returns from local concentration of human capital is found.

Overall, the available evidence is contradictory and inconclusive. OLS estimates typically show a positive and significant impact of average education on individual wages. However, when IV estimation is used to circumvent identification problems, the coefficient on average education remains positive but statistically insignificant. This raises the question about the quality of the instruments: weak instruments result in the inflation of standard errors and insignificant coefficients. Indeed, many of the instruments used in the previous analysis - variations in compulsory schooling 
laws across the states, the presence of land-grant colleges and the demographic structure of cities are likely to be weak. To summarise, endogeneity issues and the quality of the instruments remain the major issues in empirical analysis of human capital externalities on the micro-level.

\section{Identification of human capital spillovers using Russian data}

In order to identify human capital externalities, this paper exploits a natural experiment provided by the process of economic transition in Russia. We argue that the educational structure of cities under central planning was determined by the government rather than the market; thus the average educational attainment in cities at the end of communism can be regarded as exogenous with respect to market wages that prevailed after the start of transition.

The main justification for this approach centres upon several features of the planned economies, most importantly the wage setting mechanism the USSR. Indeed, the Soviet economy was characterized by huge job vacancies with no open unemployment. Earnings of workers and salaried employees were determined according to the wage grid which primarily took into account position's respective skill level and the responsibilities it required (Geisheckerb and Haisken-DeNew, 2002). For ideological reasons mainly, the grid implied extremely small wage differentials and low returns to education; in fact, it resulted in the most egalitarian distribution of income in the world (Munich et al., 2002). The ultimate effect of the grid was that wages had little to do with actual productivity of workers, including potential productivity gains from local concentration of human capital. This effectively precluded any sorting based on productivity and wage differences in the Soviet time. ${ }^{7}$

Neither were differences in the price levels across regions conducive to selective migration. Full employment and wage compression were coupled with only slightly varying prices, rents and infrastructure costs across the regions and implied a rather uniform standard of living in different parts of the country. When wages and costs of living are centralized and do not vary much, an individual preferences with

\footnotetext{
${ }^{7}$ As discussed above, such sorting represents a major problem of identification of human capital spillovers in the established market economies.
} 
respect to the place of residence depend on location-specific amenities ${ }^{8}$ which include climate, urban conditions and environmental quality. These remaining incentives to migration were dealt with by introducing migration controls. ${ }^{9}$

Despite the mentioned equalisation across the Russian regions, they differed substantially in terms of educational composition. The share of college graduates among adult population varied across the 88 regions from $4.3 \%$ to $26.4 \%$ in 1989 , the time of the last census in the USSR. It is usually assumed that the variation in the average education across regions is due to differences in local production of education as well as skill-biased migration (e.g., Jurajda, 2004). However, Russian data on the regional level from 1989 are at odds with the assumed role of regional colleges. As of 1989, twelve out of eighty-eight regions in the country did not have own universities/colleges and 76 had at least one; nevertheless, the difference in the college share between these two groups of regions is negligible and not statistically significant in $1989-9.82 \%$ versus $10.06 \%$. In contrast, by 2002 the respective shares became $11.09 \%$ and $14.52 \%$, and the difference between the two is statistically significant.

The above result that the presence of colleges had little effect on the college share in the Soviet time is consistent with the role of administrative allocation of labour and migration controls in the USSR. In particular, the government regulated the number of specialists produced by the educational institutions in order to match them with the accounted needs of the planned economy and determined not only the overall composition of the workforce with respect to education, but also the distribution across the regions. For example, administrative allocation of labour was applied to graduates of higher education and secondary special educational institutions (Clarke, 1999). After completion of their studies, the graduates received their first allocation, often in another region, where they had to work for three years. Apparently, the idea

\footnotetext{
${ }^{8}$ That is, pure consumption amenities as opposed to production ones.

${ }^{9}$ After the World War II, internal migration was managed through a number of mechanisms. First, denial of internal passports for citizens from rural areas until the late 1950s effectively prevented them from moving anywhere, most importantly to the cities. Seventy seven cities of the USSR, mostly large ones, were subject to immigration restrictions until the collapse of the Union (hence, a notion of "restricted cities" in the literature - see, e.g., Gang and Stuart, 1999). To redistribute labour from surplus to deficit regions, the government widely used a system of organized recruitment for labour ("orgnabor"). Non-market mechanisms such as those mentioned above were in the later years supplemented with attempts to emulate market forces (regional wage differentials, housing subsidies, paid moving expenses, etc.) in order to reallocate labour to the areas which were considered by the communist government as particularly important (in various senses, not necessarily economically).
} 
behind was that the graduates would settle in the destination regions for good. ${ }^{10}$ All these facts provide evidence of exogeneity of the average educational attainment in the Russian regions.

The above said has immediate implications for identification of human capital externalities in Russia and other formerly communist countries. It appears that the pre-transition educational structure of regions (or cities) is a valid instrument for the (presumably endogenous) educational structure of regions/cities in the post-transition period. And it is a strong instrument: the intensity of inter-regional migration flows in the transition countries has been rather low despite the enormous discrepancies in average wages and unemployment rates across regions - a well-documented fact in the transition literature. ${ }^{11}$ Thus, one can expect that the pre- and post-transition educational structures of cities are highly correlated. More than that, the pre-transitional educational structure of cities can be considered not only a valid and strong instrument, but also as a predetermined measure of average human capital that can be used in place of the respective contemporaneous measure. Clearly, these identification strategies are unavailable in the context of the established market economies. Finally, we note that the identification strategy based on the historical locations of higher education establishments (the respective variable is extensively used as an instrument for the average level of education in cities) remains valid in the transition context as these establishments were set up by the government, not the market, and hence, their distribution across cities is likely to be orthogonal to the demand for skilled labour and city-specific productivity shocks in the emerging market economy.

\section{Data description}

Empirical analysis is based on RLMS (Russia Longitudinal Monitoring Survey) data, one of the few representative surveys of the Russian population which contains indi-

\footnotetext{
${ }^{10}$ Some authors argue that this system was not very stringent since it did not prevent people from finding another job or migrating into another area (see, e.g., Clarke, 1999). Nevertheless, even if people with certain qualification left a particular area, the "central planner" could easily substitute similar individuals for them.

${ }^{11}$ Since the start of transition in 1992, the overall inter-regional migration rates in Russia have been low both compared with other countries and with the Soviet time when the state directed migration/labour movement through educational placement and job placement (see e.g., Andrienko and Guriev, 2002 and Hill, 2004). There is substantial evidence that the labour market mobility in the formerly
} 
vidual-level data on about 8000 adults living in 32 out of 89 administrative regions of the country ${ }^{12}$. The RLMS sampling sites include 39 cities of which 15 are administrative centres with population (as of 1994) varying between 230 and 8630 thousand inhabitants and other, generally smaller, cities with population in the range of 11 to 275 thousands. The study is based on data from the fifth round of the survey implemented in 1994, which is a compromise solution in view of the following trade-off. If data come from earlier waves, i.e. they are collected at the very beginning of the transition process, the argument for treating the contemporaneous level of education in cities as exogenous becomes stronger. Similarly, if contemporaneous average education is instrumented with pre-transition average education, the instrument becomes stronger when earlier data are chosen. However, with data from the early transition period the assumption that wages reflect marginal productivity of workers becomes quite problematic: following liberalization of prices and wages, adjustment of wages was hardly an instant process. Finally, there are data constraints related to the design of RLMS. In particular, the first phase of the survey (rounds 1 to 4 ) was implemented in 12 cities only (compared with 39 in the second phase), which are too few for identification of the coefficient on the average level of education (especially when additional city-level covariates are added). Note that the effective sample size for identification of the coefficient on average education with RLMS is 39 at best.

There are several problems with specific variables that measure wages and education. As regards wages, the earlier rounds of RLMS, including round 5, contain information on the amount of money actually received from the employer(s) during the calendar month preceding the interview rather than the monthly contractual wage. The latter is available starting with round 8 only (i.e., from 1998 on). While this is hardly a drawback in studies using data from established market economies (the two wages differ little), unavailability of data on contractual wages entails problems in the Russian case because of the wage arrears that were widespread in the economy in the 1990s. Therefore, we redefine monthly using a simple procedure that takes account of wage arrears (see definitions of variables in Appendix 1). Up to round 6, RLMS provides education data in categorical form only with no information on years of school1999). 
ing. The same applies to actual experience which is reported starting from round 8 only. Therefore, we impute years of schooling based on the highest degree obtained and define potential experience as age minus years of schooling minus seven.

The RLMS data were supplemented with additional information on educational characteristics of cities in 1989. The 1989 USSR census data on average education across cities were obtained from the respective regional branches of Goskomstat, the Russian statistical office (city-level data on education are not publicly available). These are exact data since they reflect educational attainment of all the inhabitants in each city.

Table 1 provides information on city size, share of adults with higher education in 1989 (census data) and 1994 (estimates from the RLMS), hourly wages and the number of adult respondents in each city. ${ }^{13}$ The table reveals substantial differences in the share of adults with higher education across the cities, the variation in 1989 is between 6 and 27\%. The size of the city and the college share are highly correlated; yet in 1989 Moscow was not ranked first with respect to the latter characteristic (it was surpassed by a smaller city in Moscow region). Next, the table shows that the RLMS estimate of the college share in 1994 and the exact college share in 1989 are highly correlated; though a high discrepancy between the two is also apparent. This, of course, may be related to the skill-biased migration between 1989 and $1994^{14}$. A complementary (and quite plausible) explanation is the low precision of the estimates based on the RLMS data (the survey is not representative on the regional and city levels; the number of surveyed adults in each city is several hundred at best and in some cases falls to dozens only). For example, the true (population) values for the share of people with high education in 1994 is 0.299 for Moscow and 0.247 for St. Petersburg (the figures are taken from the 5\% micro-census held in 1994) while the RLMS esti-

\footnotetext{
${ }^{12}$ This is true of the second phase of the survey, which has been implemented since 1994. In rounds 14 that were conducted in 1992-1994 the sampling sites (cities) are different from those in the later rounds.

${ }^{13}$ City names are not reported due to the RLMS confidentiality policy.

${ }^{14}$ Evidence on changes in the college share across Russian regions is consistent with significant skillbiased migration since the start of transition. Census data show that the variation of the average annual growth in the college share across 78 Russian regions (for which full data are available) increased dramatically between 1989 and 1994 (and also between 1994 and 2002) relative to the pre-transition period, e.g., between 1970 and 1989 (the coefficient of variation of the growth rate in the pre-transition period is nearly 3 times smaller compared with the same coefficient in 1989-1994 and 1994-2002). Between 1989 and 1994 several regions experienced a decrease in college share up to $13 \%$ while some regions experienced an increase of up to $33 \%$ (the average increase of the college share for the country as a whole between 1989 and 1994 was from $11.3 \%$ to $13.3 \%$, i.e. by $17.6 \%$ ).
} 
mates are 0.312 and 0.344 respectively. Thus, instrumenting contemporaneous average education in 1994 (measured with error) with education in 1989 can also help to reduce the measurement error bias.

The relationship between the share of college graduates and the number of higher education establishments in a city in 1989 is somewhat peculiar. Figures 1 and 2 show a positive correlation, which is particularly strong due to outliers - Moscow and St. Petersburg. Once these metropolitan areas are excluded, the correlation becomes much weaker. For example, the city with the highest share of college graduates in 1989 with population slightly exceeding 100000, did not host a higher education establishment in the Soviet time. ${ }^{15}$ This is a good example of how the centrally planned economy functioned: the government could achieve a target level of skill concentration in a city by using administrative allocation of resources (e.g., allocation of graduates) and not necessarily by establishing an institute or university. The implication for the analysis that follows is that the number of universities/colleges in a city in 1989 may not be a very strong instrument for the share of college graduates, at least at the early years of transition, when the educational structure of cities was still pretty close to the one created by the "central planner".

Last comment concerns the relationship between city size and the number of higher education establishments in a city in 1989. The correlation between the two is quite strong; moreover, the relationship between the two implies one university/institute per 110 thousand inhabitants.

\section{Empirical analysis}

We start with a simple OLS regression of log wages on individual characteristics (years of schooling, experience, experience squared and gender) and the RLMS estimate of the city share of adults with institute diploma in 1994. Regression results are reported in Table 2 (model 1 reported in the first column). The coefficient on the college share is 0.86 and statistically significant with standard Huber/White/sandwich estimator of variance. The latter may not be appropriate due to the correlation of error terms corresponding to individuals living in same city. Therefore model 2 estimates

\footnotetext{
${ }^{15}$ A high fraction of people with college degree in this city is due to the fact that it hosts an aerospace centre with several research institutes.
} 
the variance-covariance matrix under the assumption that observations are independent across cities, but not necessarily within cities (e.g., a standard clustering option available in Stata is applied). ${ }^{16}$ The coefficient on the college share becomes statistically insignificant. These first results should be considered with caution due to potential endogeneity of insh94 and/or its imprecise estimate based on the RLMS data, as discussed in the previous section (measurement errors in the dependent variables bias regression coefficient towards zero). Model 3 is an IV regression in which the 1994 share of people with higher education is instrumented with the respective share in 1989. The estimate of the coefficient of interests is 1.35 and significant at $5 \%$ level with variance estimates adjusted for clustering. Model 4 is identical to model 3, but the instrument is the number of higher education establishments in the cities. The results are similar to those from model 3. Finally, in model 5 we use the share of adults with institute diploma in 1989 instead of the contemporaneous college share. The results are similar to those obtained by instrumenting for insh94: an increase in the share of people with higher education (in 1989!) by one percentage point raises average wages in the respective city (in 1994) by 1.67 percent.

There are several weaknesses in this analysis. In general, there are two potentially endogenous regressors in the models: own education and average education and only the latter problem is addressed in models 3-5. Unfortunately, RLMS does not contain any instrument for individual schooling therefore the two admittedly endogenous variables have to be treated asymmetrically. Second, the above models ignore city heterogeneity (in particular, in terms of production amenities - natural resources, infrastructure, etc. that may have a direct impact on wages) ${ }^{17}$. This creates no problems as long as the average education in cities is uncorrelated with their production amenities, but is a disputable assumption. Insrumenting for the contemporaneous average education with the pre-transition values or with the number of institutes in the cities could provide a solution to the problem.

While it is generally impossible to control for all relevant city-specific characteristics, the robustness of the results can be checked by controlling for at least some

\footnotetext{
${ }^{16}$ This is a somewhat problematic approach since estimation of the variance-covariance matrix relies on the asymptotic result with number of clusters going to infinity while we have only 39 cities (clusters).

${ }^{17}$ While some amenities can be measured, most are unobservable. City characteristics cannot be controlled for with dummy variables since the latter will eliminate the effect of average education and the coefficient of interest is unidentified.
} 
important characteristics of cities. In this paper, three such characteristic are chosen: city location (geographical region defined in the RLMS), city status (whether it is an administrative centre of a region or not) and prevalence of the oil extraction industry in the city economy. However, the best way to check robustness of the results is perhaps by dropping observations from Moscow or Moscow and St. Petersburg taken together. The rationale is that these cities are obvious outliers in a number of important dimensions, e.g., size, educational attainment, number of higher education establishments, infrastructure quality, cultural amenities, etc. ${ }^{18}$

Estimation results are shown in Table 3. Model 1 is the same as model 5 in Table 1 and is replicated to serve as a benchmark (thus, analysis that follows is based on the assumption of exogeneity of the city-level education in 1989). Model 2 introduces regional dummies. They are jointly statistically significant; however, they do not change the coefficient of interest. Model 3 introduces a dummy variable for the cities whose economies are centred on the oil extraction industry; there are three such cities in RLMS: one in Komi Republic and the other two in Khanty-Mansiysk Autonomous Region. The dummy is highly significant; however, the coefficient on the college share in cities stays virtually unchanged. The same happens when a dummy for city status is included - it turns out that there is no wage premium in regional capitals (see model 4). Models 5 and 6 drop observations from Moscow and Moscow plus St. Petersburg respectively. Again, the coefficient of interest stays nearly the same as before. ${ }^{19}$

Next we consider imperfect substitutability across workers with different educational attainments by dividing the 1994 sample into two sub-samples: one containing individuals with university degree and the other one with people who obtained less schooling. Estimation results using these two sub-samples (Tables 4 and 5) show that the coefficient on average education is positive and significant in both subsamples which is consistent with the existence of educational externalities. The coefficient is somewhat smaller in the more educated sub-sample; however, the differences between the estimates based on the two sub-samples are statistically insignificant.

\footnotetext{
${ }^{18}$ A similar approach is used by Jurajda (2004) who tests robustness of results by dropping data from Prague and Brno, the two largest cities in the Czech Republic.

${ }^{19}$ Regression results also change little if additional variable for the size of the city (the number of inhabitants in 1989) which captures agglomeration effects is included.
} 
As mentioned in the section 5, one of the concerns related to using data from the early transition period is that wages may not reflect marginal productivity of workers. One possibility to check the validity of this concern is to repeat the above analysis using more recent data. Tables 6 and 7 show regression results based on RLMS data from 2002 (the specifications are equivalent to those reported for 1994 in tables 2 and 3). The relationship between individual wages and city share of people with higher education in 2002 is similar to that in 1994; and is consistent with the presence of human capital spillovers.

\section{Conclusions}

This paper centres upon the idea that the transition economies offer a unique natural experiment that makes it possible to shed some light on the controversial issue of human capital (educational) externalities. The basic assumption underlying this paper is that the average educational attainment in the Russian cities at the end of the Soviet time was orthogonal to the demand for skilled labour and city-specific productivity shocks in the emerging market economy of the 1990s. Interpreting educational attainments in the Russian cities at the end of the communist period as exogenously determined provides a solution to the severe problem of endogeneity of average human capital which is encountered in the empirical micro-level studies based on data from the established market economies.

The estimation framework in this paper is a standard Mincerian regression augmented with the share of university/institute graduates in the cities the respondents live in. Regression results are consistent with the presence of human capital externalities. In particular, our results show that one percent increase in the share of people with higher education in a city results in the increase of city residents' earnings by 1.5-2 percent. These results hold in both 1994 and 2002, i.e., early in the transition process and a decade after the start of the reform process, are robust to the inclusion of several city-level controls and, more important, exclusion of Moscow and St. Petersburg from the sample. Interestingly, the estimated magnitude of the externality is quite similar to the findings by Moretti (2004) whose study is based on US data.

At least two caveats should be made, however. Our analysis proceeds under the assumption of exogeneity of individual schooling in the wage regression, which is 
entirely due to the lack of satisfactory instruments in the RLMS. Also, the effective sample size for identification of the coefficient on average education is 39 observations only, which is the number of cities in the RLMS.

\section{References}

Acemoglu, D. (1996) "A Microfoundation for Social Increasing Returns in Human Capital Accumulation”, Quarterly Journal of Economics, p. 779-804.

Acemoglu, D. and Angrist, J. (2000) "How Large are Human Capital Externalities? Evidence from Compulsory Schooling Laws", unpublished manuscript, MIT.

Andrienko, Y., Guriev, S. (2002) "Determinants of Interregional Mobility in Russia: Evidence from Panel Data", unpublished manuscript, CEFiR, Moscow.

Buckley, G. (1995), “The Myth of Managed Migration: Migration Control and Market in the Soviet Period", Slavic Review, Vol. 54, No. 4, p. 896-916.

Card, D. (1999), "The Casual Effect of Education on Earnings", in: Ashenfelter, O., Card, D. "Handbook of Labour Economics", Vol. 3A, North Holland.

Ciccone, A., Peri, G. (2002), "Identifying Human Capital Externalities: Theory with an Application to US Cities", unpublished manuscript, Universitat Pompeu Fabra.

Clarke, S. (1999), "The Formation of a Labour Market in Russia", Edward Elgar, Cheltenham, UK.

Faggio, G. and Konings, J. Gross Job Flows and Firm Growth in Transition Countries: Evidence Using Firm Level Data on Five Countries. CEPR Discussion paper 2261.

Gang, I., Stuart, R. (1995), "Mobility where Mobility is Illegal: Internal Migration and City Growth in the Soviet Union", Journal of Population Economics, Vol. 12, p. 117-134.

Geisheckerb and Haisken-DeNewc (2002) "Riding the Transition Roller-Coaster: Flexibility and The Inter-Industry Wage Structure in Russia", German Institute for Economic Research Discussion Paper 280.

Hill, F. (2004) "Eurasia on the Move": The Regional Implications of Mass Labour Migration From Central Asia to Russia, Brookings Institution.

Jurajda, S. (2004) “Are There Increasing Returns to Local Concentration of Skills? Evidence on Wages and Returns to Education in Transition". CERGE-EI working paper.

Katz, L. F. and Murphy, K. M. (1992) “Changes in Relative Wages, 1963-1987: Supply and Demand Factors", Quarterly Journal of Economics, Vol. 107, No. 1.

Konstantinova Vernon, V. (2002) "Returns to Human Capital in Transitional Russia", Department of Economics, The University of Texas at Austin.

Krueger, A., Lindahl, M. (2001), "Education for Growth: Why and for Whom?”, Journal of Economic Literature, Vol. XXXIX, p. 1101-1136. 
Lucas, R. (1988) "On the Mechanics of Economic Development", Journal of Monetary Economics, Vol. 22, pp. 3-42.

Moretti, E. (2002) "Estimating the Social Return to Higher Education: Evidence from Longitudinal and Repeated Cross-Sectional Data", NBER Working Paper No. 9108.

Moretti, E. (2003) "Human Capital Externalities in Cities", NBER Working Paper No. 9641.

Munich, D., Svejnar, J., Terrel, K. (2002), "Returns to Human Capital under the Communist Wage Grid And During the Transition to a Market Economy", CERGE-EI working paper.

Murphy, K., Shleifer, A., Vishny, R. (1991), "The Allocation for Talent: The Implications for Growth", Quarterly Journal of Economics, Vol. 106, pp. 503-530.

Psacharopoulos, G., Patrinos, H. (2002) "Returns to Investment to Education: A Further Update", World Bank Policy Research Working Paper No. 2881.

Rauch, J. (1993), "Productivity Gains from Geographic Concentration of Human Capital: Evidence from the Cities", Journal of Urban Economics, Vol. 34, p. 380400 .

Rudd, J. (2001), "Empirical Evidence on Human Capital Spillovers", unpublished manuscript, Federal Reserve Board.

Sianesi, B., Van Reenen, J. (2003), "The Returns to Education: A Review of the Empirical Macro-Economic Literature", Journal of Economic Surveys, Vol. 17, No.2.

Silva, J. (2002) "Human Capital Externalities or Sorting? Evidence from a Displaced Workers Sample", unpublished manuscript, IUE.

Spagat, M. (2002) "Human Capital, Growth and Inequality in Transition Economies", CEPR Discussion Paper No. 3556.

Venniker, R. (2000) "Social Returns to Education: A Survey of Recent Literature on Human Capital Externalities", CPB report 00/1. 
Table 1. Average education and wages in the RLMS cities

\begin{tabular}{|c|c|c|c|c|c|c|}
\hline city & I & (pop89) & (insh89) & (insh94) & (wage) & (adults) \\
\hline 1 & | & 5020.0 & 0.22 & 0.34 & 26.69 & 369 \\
\hline 2 & | & 8967.0 & 0.27 & 0.31 & 31.09 & 589 \\
\hline 3 & I & 234.9 & 0.13 & 0.21 & 29.67 & 203 \\
\hline 4 & i & 47.2 & 0.11 & 0.13 & 32.90 & 164 \\
\hline 5 & i & 341.0 & 0.15 & 0.26 & 19.45 & 229 \\
\hline 6 & | & 69.8 & 0.08 & 0.11 & 16.52 & 157 \\
\hline 7 & | & 540.0 & 0.16 & 0.24 & 16.10 & 224 \\
\hline 8 & | & 1403.0 & 0.15 & 0.26 & 22.22 & 227 \\
\hline 9 & | & 41.9 & 0.06 & 0.06 & 15.44 & 141 \\
\hline 10 & | & 450.0 & 0.14 & 0.20 & 19.79 & 232 \\
\hline 11 & i & 34.5 & 0.07 & 0.07 & 14.30 & 132 \\
\hline 12 & i & 1094.0 & 0.16 & 0.16 & 14.81 & 244 \\
\hline 13 & I & 904.6 & 0.18 & 0.23 & 18.90 & 209 \\
\hline 14 & I & 65.6 & 0.08 & 0.22 & 16.16 & 134 \\
\hline 15 & i & 91.9 & 0.08 & 0.14 & 18.81 & 240 \\
\hline 16 & i & 621.0 & 0.19 & 0.25 & 21.92 & 189 \\
\hline 17 & I & 62.9 & 0.10 & 0.12 & 16.84 & 97 \\
\hline 18 & I & 1107.0 & 0.13 & 0.19 & 21.98 & 227 \\
\hline 19 & i & 355.5 & 0.12 & 0.16 & 23.41 & 204 \\
\hline 20 & i & 104.0 & 0.12 & 0.11 & 24.05 & 168 \\
\hline 21 & I & 270.7 & 0.07 & 0.11 & 19.13 & 216 \\
\hline 22 & I & 110.2 & 0.06 & 0.05 & 24.64 & 175 \\
\hline 23 & i & 501.9 & 0.16 & 0.19 & 24.98 & 179 \\
\hline 24 & i & 247.8 & 0.13 & 0.17 & 50.15 & 184 \\
\hline 25 & I & 233.2 & 0.11 & 0.16 & 19.13 & 205 \\
\hline 26 & | & 870.0 & 0.16 & 0.22 & 30.37 & 213 \\
\hline 27 & i & 634.0 & 0.19 & 0.26 & 28.50 & 225 \\
\hline 28 & I & 64.3 & 0.06 & 0.04 & 23.46 & 140 \\
\hline 29 & I & 22.1 & 0.09 & 0.19 & 40.08 & 26 \\
\hline 30 & | & 9.5 & 0.09 & 0.06 & 23.99 & 47 \\
\hline 31 & I & 136.0 & 0.21 & 0.48 & 25.14 & 27 \\
\hline 32 & i & 100.6 & 0.27 & 0.29 & 16.98 & 24 \\
\hline 33 & I & 59.2 & 0.16 & 0.10 & 25.38 & 20 \\
\hline 34 & I & 58.3 & 0.14 & 0.32 & 24.08 & 28 \\
\hline 35 & i & 130.0 & 0.11 & 0.09 & 24.54 & 32 \\
\hline 36 & I & 109.2 & 0.20 & 0.21 & 31.89 & 24 \\
\hline 37 & I & 209.1 & 0.16 & 0.31 & 28.94 & 29 \\
\hline 38 & I & 94.9 & 0.11 & 0.21 & 29.16 & 19 \\
\hline 39 & I & 15.8 & 0.09 & 0.06 & 14.33 & 16 \\
\hline
\end{tabular}


Table 2. Estimation results: alternative specifications

\begin{tabular}{|c|c|c|c|c|c|}
\hline Model : & 1 & 2 & 3 & 4 & 5 \\
\hline Depvar: & Inwage & Inwage & Inwage & Inwage & Inwage \\
\hline intcpt & $\begin{array}{l}1.968 * * \\
(0.080)\end{array}$ & $\begin{array}{l}1.968 * * \\
(0.116)\end{array}$ & $\begin{array}{l}1.914 \text { ** } \\
(0.124)\end{array}$ & $\begin{array}{l}1.879 * * \\
(0.135)\end{array}$ & $\begin{array}{l}1.906 \text { *t } \\
(0.124)\end{array}$ \\
\hline insh94 & $\begin{array}{l}0.859 * * \\
(0.164)\end{array}$ & $\begin{array}{r}0.859 \\
(0.498)\end{array}$ & $\begin{array}{c}1.350 * \\
(0.558)\end{array}$ & $\begin{array}{c}1.672 * \\
(0.685)\end{array}$ & \\
\hline schn & $\begin{array}{l}0.042 * * \\
(0.006)\end{array}$ & $\begin{array}{l}0.042 * * \\
(0.006)\end{array}$ & $\begin{array}{l}0.039 * * \\
(0.006)\end{array}$ & $\begin{array}{l}0.036 * * \\
(0.008)\end{array}$ & $\begin{array}{l}0.042 \text { * } \\
(0.006)\end{array}$ \\
\hline expp & $\begin{array}{l}0.022 * * \\
(0.004)\end{array}$ & $\begin{array}{l}0.022 * * \\
(0.004)\end{array}$ & $\begin{array}{l}0.022 * * \\
(0.004)\end{array}$ & $\begin{array}{l}0.023 * * \\
(0.004)\end{array}$ & $\begin{array}{c}0.022 * * \\
(0.004)\end{array}$ \\
\hline expp2 & $\begin{array}{l}-0.055 * * \\
(0.008)\end{array}$ & $\begin{array}{l}-0.055 * * \\
(0.009)\end{array}$ & $\begin{array}{l}-0.057 * \star \\
(0.009)\end{array}$ & $\begin{array}{l}-0.058 * * \\
(0.008)\end{array}$ & $\begin{array}{l}-0.055 * * \\
(0.009)\end{array}$ \\
\hline sex & $\begin{array}{l}0.299 * * \\
(0.027)\end{array}$ & $\begin{array}{l}0.299 * * \\
(0.030)\end{array}$ & $\begin{array}{l}0.299 * * \\
(0.030)\end{array}$ & $\begin{array}{l}0.299 * * \\
(0.030)\end{array}$ & $\begin{array}{c}0.30 * * \\
(0.029)\end{array}$ \\
\hline insh89 & & & & & $\begin{array}{l}1.672^{\star \star} \\
(0.551)\end{array}$ \\
\hline \# obs : & 2801 & 2801 & 2801 & 2801 & 2801 \\
\hline$R-s q$ & 0.104 & 0.104 & 0.101 & 0.096 & 0.111 \\
\hline
\end{tabular}

Note: Standard errors in parentheses with $\mathrm{p}<0.05=*, \mathrm{p}<0.01=* *$. All models are Mincerian-type regressions of log wages on individual characteristics and the share of people with university degree in cities (either insh94 or insh89). Model 1 is an OLS regression where the share of people with university degree is estimated from the RLMS data (insh94); standard errors are calculated using white heteroscedasticity robust estimator of variance. Model 2 is the same as model 1, but the standard errors are adjusted for correlation within cities (by using "cluster" option in Stata). Model 3 is an IV regression where the share of people with university degree in a city in 1994 (insh94) is instrumented with the respective share in 1989 (insh89). Model 4 repeats model 3, but the instrument for the share of people with university degree in a city in 1994 is the number of higher education establishments in a city in 1989 (noinst89). Model 5 is an OLS regression that uses insh89, the share of people with high education in 1989, which is considered as predetermined variable, instead of insh94. 
Table 3. Estimation results: robustness check for the basic specification

\begin{tabular}{|c|c|c|c|c|c|c|}
\hline Model : & 1 & 2 & 3 & 4 & 5 & 6 \\
\hline Depvar: & Inwage & Inwage & Inwage & Inwage & lnwage & Inwage \\
\hline intcpt & $\begin{array}{l}1.906 * * \\
(0.124)\end{array}$ & $\begin{array}{l}1.876 * * \\
(0.189)\end{array}$ & $\begin{array}{l}1.839 * * \\
(0.171)\end{array}$ & $\begin{array}{l}1.814^{*} \\
(0.180)\end{array}$ & $\begin{array}{l}1.744^{*} \\
(0.164)\end{array}$ & $\begin{array}{l}1.906 * * \\
(0.191)\end{array}$ \\
\hline insh89 & $\begin{array}{l}1.672 * * \\
(0.551)\end{array}$ & $\begin{array}{l}1.780 * * \\
(0.621)\end{array}$ & $\begin{array}{l}1.979 * * \\
(0.512)\end{array}$ & $\begin{array}{l}2.163 * * \\
(0.724)\end{array}$ & $\begin{array}{l}1.884 \text { * } \\
(0.808)\end{array}$ & $\begin{array}{l}1.899 * \\
(0.808)\end{array}$ \\
\hline $\operatorname{schn}$ & $\begin{array}{l}0.042^{* *} \\
(0.006)\end{array}$ & $\begin{array}{l}0.044 * * \\
(0.006)\end{array}$ & $\begin{array}{l}0.045 * * \\
(0.006)\end{array}$ & $\begin{array}{l}0.045^{*} * \\
(0.006)\end{array}$ & $\begin{array}{l}0.048 * * \\
(0.006)\end{array}$ & $\begin{array}{l}0.046 * * \\
(0.006)\end{array}$ \\
\hline expp & $\begin{array}{l}0.022 * * \\
(0.004)\end{array}$ & $\begin{array}{l}0.020 * * \\
(0.004)\end{array}$ & $\begin{array}{l}0.018 * * \\
(0.004)\end{array}$ & $\begin{array}{l}0.018^{*} \\
(0.004)\end{array}$ & $\begin{array}{l}0.020 * * \\
(0.004)\end{array}$ & $\begin{array}{l}0.021 \text { ** } \\
(0.004)\end{array}$ \\
\hline expp2 & $\begin{array}{l}-0.055 * * \\
(0.009)\end{array}$ & $\begin{array}{l}-0.051 * * \\
(0.008)\end{array}$ & $\begin{array}{l}-0.047 * * \\
(0.008)\end{array}$ & $\begin{array}{l}-0.047 * \star \\
(0.008)\end{array}$ & $\begin{array}{l}-0.050 * * \\
(0.008)\end{array}$ & $\begin{array}{l}-0.052 * \star \\
(0.008)\end{array}$ \\
\hline sex & $\begin{array}{c}0.30 * \star \\
(0.029)\end{array}$ & $\begin{array}{l}0.308 * \star \\
(0.026)\end{array}$ & $\begin{array}{l}0.308 * * \\
(0.026)\end{array}$ & $\begin{array}{l}0.308 * * \\
(0.026)\end{array}$ & $\begin{array}{l}0.30 * * \\
(0.028)\end{array}$ & $\begin{array}{c}0.295 * \star \\
(0.029)\end{array}$ \\
\hline oil & & & $\begin{array}{l}0.626 * * \\
(0.159)\end{array}$ & $\begin{array}{l}0.614 * * \\
(0.164)\end{array}$ & $\begin{array}{l}0.618 * * \\
(0.163)\end{array}$ & $\begin{array}{l}0.617 \text { ** } \\
(0.163)\end{array}$ \\
\hline captlr & & & & $\begin{array}{c}-0.022 \\
(0.067)\end{array}$ & $\begin{array}{r}-0.007 \\
(0.071)\end{array}$ & $\begin{array}{c}-0.007 \\
(0.071)\end{array}$ \\
\hline Regg & & Yes & Yes & Yes & Yes & Yes \\
\hline \# obs : & 2801 & 2801 & 2801 & 2801 & 2511 & 2348 \\
\hline$R-s q$ & 0.111 & 0.19 & 0.218 & 0.218 & 0.221 & 0.223 \\
\hline
\end{tabular}

Note: Standard errors in parentheses with $\mathrm{p}<0.05=\star, \mathrm{p}<0.01=\star \star$. All models represent Mincerian-type regressions of log wages on individual characteristics plus the share of people with university degree in cities (insh89). Model 1 is a basic specification without additional controls. All models are estimated using OLS. Standard errors are adjusted for correlation within cities. 
Table 4. Estimation results: test for imperfect substitutability, sub-sample of workers without university degree

\begin{tabular}{|c|c|c|c|c|c|c|}
\hline Model : & 1 & 2 & 3 & 4 & 5 & 6 \\
\hline Depvar: & lnwage & lnwage & Inwage & Inwage & Inwage & Inwage \\
\hline intcpt & $\begin{array}{l}2.056 * \star \\
(0.143)\end{array}$ & $\begin{array}{l}2.063 * \star \\
(0.197)\end{array}$ & $\begin{array}{l}2.067 * \star \\
(0.172)\end{array}$ & $\begin{array}{l}2.032 * \star \\
(0.196)\end{array}$ & $\begin{array}{l}1.979 * * \\
(0.187)\end{array}$ & $\begin{array}{l}2.155 * \star \\
(0.214)\end{array}$ \\
\hline insh89 & $\begin{array}{l}1.658 * \star \\
(0.612)\end{array}$ & $\begin{array}{l}1.822 * \star \\
(0.684)\end{array}$ & $\begin{array}{l}1.983 * * \\
(0.583)\end{array}$ & $\begin{array}{c}2.242 * \\
(0.894)\end{array}$ & $\begin{array}{c}1.918 * \\
(0.974)\end{array}$ & $\begin{array}{l}1.917 \star \\
(0.973)\end{array}$ \\
\hline schn & $\begin{array}{r}0.021 \\
(0.012)\end{array}$ & $\begin{array}{r}0.020 \\
(0.010)\end{array}$ & $\begin{array}{c}0.018 * \\
(0.009)\end{array}$ & $\begin{array}{c}0.018 * \\
(0.009)\end{array}$ & $\begin{array}{c}0.021 * \\
(0.010)\end{array}$ & $\begin{array}{l}0.022 * \\
(0.010)\end{array}$ \\
\hline expp & $\begin{array}{l}0.025 * * \\
(0.004)\end{array}$ & $\begin{array}{l}0.025 * * \\
(0.004)\end{array}$ & $\begin{array}{l}0.022 * \star \\
(0.004)\end{array}$ & $\begin{array}{l}0.022 * \star \\
(0.004)\end{array}$ & $\begin{array}{l}0.023 * * \\
(0.004)\end{array}$ & $\begin{array}{l}0.023 * * \\
(0.004)\end{array}$ \\
\hline expp2 & $\begin{array}{l}-0.062 * \star \\
(0.008)\end{array}$ & $\begin{array}{l}-0.060 * * \\
(0.008)\end{array}$ & $\begin{array}{l}-0.055 * \star \\
(0.008)\end{array}$ & $\begin{array}{l}-0.055 * \star \\
(0.008)\end{array}$ & $\begin{array}{l}-0.058 * \star \\
(0.009)\end{array}$ & $\begin{array}{l}-0.057 * \star \\
(0.009)\end{array}$ \\
\hline sex & $\begin{array}{l}0.330 * \star \\
(0.038)\end{array}$ & $\begin{array}{l}0.332 * \star \\
(0.034)\end{array}$ & $\begin{array}{l}0.328 * \star \\
(0.034)\end{array}$ & $\begin{array}{l}0.328 * \star \\
(0.034)\end{array}$ & $\begin{array}{l}0.312 * \star \\
(0.035)\end{array}$ & $\begin{array}{l}0.317 * \star \\
(0.036)\end{array}$ \\
\hline oil & & & $\begin{array}{l}0.622 * \star \\
(0.182)\end{array}$ & $\begin{array}{l}0.607 * \star \\
(0.185)\end{array}$ & $\begin{array}{l}0.615 * \star \\
(0.184)\end{array}$ & $\begin{array}{l}0.615 * \star \\
(0.184)\end{array}$ \\
\hline captlr & & & & $\begin{array}{c}-0.029 \\
(0.080)\end{array}$ & $\begin{array}{c}-0.008 \\
(0.084)\end{array}$ & $\begin{array}{c}-0.008 \\
(0.084)\end{array}$ \\
\hline Regg & & Yes & Yes & Yes & Yes & Yes \\
\hline \# obs : & 2076 & 2076 & 2076 & 2076 & 1892 & 1798 \\
\hline$R-s q$ & 0.097 & 0.187 & 0.217 & 0.217 & 0.218 & 0.224 \\
\hline
\end{tabular}

Note: Standard errors in parentheses with $\mathrm{p}<0.05=\star, \mathrm{p}<0.01=\star *$. All models represent Mincerian-type regressions of log wages on individual characteristics plus the share of people with university degree in cities (insh89). Model 1 is a basic specification without additional controls. All models are estimated using OLS. Standard errors are adjusted for correlation within cities. 
Table 5. Estimation results: test for imperfect substitutability, sub-sample of workers with university degree

\begin{tabular}{|c|c|c|c|c|c|c|}
\hline Model : & 1 & 2 & 3 & 4 & 5 & 6 \\
\hline Depvar: & Inwage & Inwage & Inwage & Inwage & lnwage & Inwage \\
\hline intcpt & $\begin{array}{c}2.003 * \\
(0.795)\end{array}$ & $\begin{array}{l}2.192 * \star \\
(0.819)\end{array}$ & $\begin{array}{c}1.947 \star \\
(0.801)\end{array}$ & $\begin{array}{c}1.925 * \\
(0.790)\end{array}$ & $\begin{array}{r}1.307 \\
(0.768)\end{array}$ & $\begin{array}{l}2.073 * \star \\
(0.666)\end{array}$ \\
\hline insh89 & $\begin{array}{l}1.619 * \star \\
(0.543)\end{array}$ & $\begin{array}{r}1.177 \\
(0.665)\end{array}$ & $\begin{array}{l}1.489 * \star \\
(0.568)\end{array}$ & $\begin{array}{l}1.744 * \star \\
(0.570)\end{array}$ & $\begin{array}{c}1.432 \star \\
(0.709)\end{array}$ & $\begin{array}{l}1.710 * \\
(0.697)\end{array}$ \\
\hline schn & $\begin{array}{r}0.045 \\
(0.053)\end{array}$ & $\begin{array}{r}0.041 \\
(0.053)\end{array}$ & $\begin{array}{r}0.051 \\
(0.052)\end{array}$ & $\begin{array}{r}0.051 \\
(0.052)\end{array}$ & $\begin{array}{r}0.091 \\
(0.055)\end{array}$ & $\begin{array}{r}0.036 \\
(0.048)\end{array}$ \\
\hline expp & $\begin{array}{c}0.021 * \\
(0.009)\end{array}$ & $\begin{array}{r}0.018 \\
(0.009)\end{array}$ & $\begin{array}{r}0.018 \\
(0.009)\end{array}$ & $\begin{array}{r}0.018 \\
(0.010)\end{array}$ & $\begin{array}{c}0.023^{\star} \\
(0.010)\end{array}$ & $\begin{array}{l}0.031 \text { ** } \\
(0.008)\end{array}$ \\
\hline expp2 & $\begin{array}{l}-0.062 * \star \\
(0.022)\end{array}$ & $\begin{array}{l}-0.054 * \\
(0.022)\end{array}$ & $\begin{array}{l}-0.054 \star \\
(0.022)\end{array}$ & $\begin{array}{l}-0.054 \star \\
(0.022)\end{array}$ & $\begin{array}{l}-0.061 \star \\
(0.025)\end{array}$ & $\begin{array}{l}-0.078 * \star \\
(0.022)\end{array}$ \\
\hline sex & $\begin{array}{c}0.20 * \star \\
(0.042)\end{array}$ & $\begin{array}{l}0.218 * \star \\
(0.042)\end{array}$ & $\begin{array}{l}0.228 * \star \\
(0.042)\end{array}$ & $\begin{array}{l}0.227 * \star \\
(0.042)\end{array}$ & $\begin{array}{l}0.223 * \star \\
(0.049)\end{array}$ & $\begin{array}{l}0.195 * \star \\
(0.048)\end{array}$ \\
\hline oil & & & $\begin{array}{l}0.629 * \star \\
(0.111)\end{array}$ & $\begin{array}{l}0.605 * \star \\
(0.131)\end{array}$ & $\begin{array}{l}0.623 * \star \\
(0.130)\end{array}$ & $\begin{array}{l}0.599 * \star \\
(0.133)\end{array}$ \\
\hline captlr & & & & $\begin{array}{c}-0.038 \\
(0.061)\end{array}$ & $\begin{array}{c}-0.030 \\
(0.065)\end{array}$ & $\begin{array}{l}-0.039 \\
(0.065)\end{array}$ \\
\hline Regg & & Yes & Yes & Yes & Yes & Yes \\
\hline \# obs : & 725 & 725 & 725 & 725 & 619 & 550 \\
\hline$R-s q$ & 0.055 & 0.123 & 0.149 & 0.149 & 0.16 & 0.165 \\
\hline
\end{tabular}

Note: Standard errors in parentheses with $\mathrm{p}<0.05=\star, \mathrm{p}<0.01=\star \star$. All models represent Mincerian-type regressions of log wages on individual characteristics plus the share of people with university degree in cities (insh89). Model 1 is a basic specification without additional controls. All models are estimated using OLS. Standard errors are adjusted for correlation within cities. 
Table 6. Estimation results: alternative specifications, data from 2002

\begin{tabular}{|c|c|c|c|c|c|}
\hline Model : & 1 & 2 & 3 & 4 & 5 \\
\hline Depvar: & Inwage & lnwage & Inwage & Inwage & lnwage \\
\hline intcpt & $\begin{array}{l}1.579 * * \\
(0.075)\end{array}$ & $\begin{array}{l}1.579 * * \\
(0.114)\end{array}$ & $\begin{array}{l}1.425 * * \\
(0.133)\end{array}$ & $\begin{array}{l}1.280 * * \\
(0.169)\end{array}$ & $\begin{array}{c}1.50 * \star \\
(0.113)\end{array}$ \\
\hline insh02 & $\begin{array}{l}1.747 * * \\
(0.146)\end{array}$ & $\begin{array}{l}1.747 * \star \\
(0.622)\end{array}$ & $\begin{array}{l}2.925 * * \\
(0.715)\end{array}$ & $\begin{array}{l}4.034 * * \\
(0.687)\end{array}$ & \\
\hline schn & $\begin{array}{l}0.053 * \star \\
(0.005)\end{array}$ & $\begin{array}{l}0.053 * * \\
(0.007)\end{array}$ & $\begin{array}{l}0.045 * * \\
(0.007)\end{array}$ & $\begin{array}{l}0.037 * * \\
(0.007)\end{array}$ & $\begin{array}{l}0.053 * * \\
(0.006)\end{array}$ \\
\hline expp & $\begin{array}{l}0.017 * * \\
(0.003)\end{array}$ & $\begin{array}{l}0.017 * \star \\
(0.003)\end{array}$ & $\begin{array}{l}0.019 * * \\
(0.003)\end{array}$ & $\begin{array}{l}0.020 * * \\
(0.003)\end{array}$ & $\begin{array}{l}0.018 * * \\
(0.003)\end{array}$ \\
\hline expp2 & $\begin{array}{l}-0.043 * * \\
(0.006)\end{array}$ & $\begin{array}{l}-0.043 * * \\
(0.006)\end{array}$ & $\begin{array}{l}-0.047 * \star \\
(0.006)\end{array}$ & $\begin{array}{l}-0.051 * \star \\
(0.006)\end{array}$ & $\begin{array}{l}-0.046 * \star \\
(0.005)\end{array}$ \\
\hline sex & $\begin{array}{l}0.267 * * \\
(0.023)\end{array}$ & $\begin{array}{l}0.267 * \star \\
(0.032)\end{array}$ & $\begin{array}{l}0.266 * * \\
(0.031)\end{array}$ & $\begin{array}{l}0.265 * \star \\
(0.029)\end{array}$ & $\begin{array}{l}0.271 * \star \\
(0.031)\end{array}$ \\
\hline insh89 & & & & & $\begin{array}{l}2.980 * * \\
(0.413)\end{array}$ \\
\hline \# obs : & 3101 & 3101 & 3101 & 3101 & 3101 \\
\hline$R-s q$ & 0.127 & 0.127 & 0.109 & 0.059 & 0.162 \\
\hline
\end{tabular}

Note: Standard errors in parentheses with $\mathrm{p}<0.05=*, \mathrm{p}<0.01=* *$. All models are Mincerian-type regressions of log wages on individual characteristics and the share of people with university degree in cities (either insh02 or insh89). Model 1 is an OLS regression where the share of people with university degree is estimated from the RLMS data (insh02); standard errors are calculated using White heteroscedasticity robust estimator of variance. Model 2 is the same as model 1, but the standard errors are adjusted for correlation within cities (by using "cluster" option in Stata). Model 3 is an IV regression where the share of people with university degree in a city in 2002 (insh02) is instrumented with the respective share in 1989 (insh89). Model 4 repeats model 3, but the instrument for the share of people with university degree in a city in 1994 is the number of higher education establishments in a city in 1989 (noinst89). Model 5 is an OLS regression that uses insh89, the share of people with high education in 1989, which is considered as predetermined variable, instead of insh02. 
Table 7. Estimation results: robustness check for the basic specification, data from 2002

\begin{tabular}{|c|c|c|c|c|c|c|}
\hline Model : & 1 & 2 & 3 & 4 & 5 & 6 \\
\hline Depvar: & Inwage & Inwage & Inwage & Inwage & Inwage & Inwage \\
\hline intcpt & $\begin{array}{l}1.50 * * \\
(0.113)\end{array}$ & $\begin{array}{l}1.689 * * \\
(0.152)\end{array}$ & $\begin{array}{l}1.643 * * \\
(0.148)\end{array}$ & $\begin{array}{l}1.575 * * \\
(0.159)\end{array}$ & $\begin{array}{l}1.50 * * \\
(0.148)\end{array}$ & $\begin{array}{l}1.451 \text { ** } \\
(0.116)\end{array}$ \\
\hline insh89 & $\begin{array}{l}2.980 * \star \\
(0.413)\end{array}$ & $\begin{array}{l}2.298 * \star \\
(0.481)\end{array}$ & $\begin{array}{l}2.418 * \star \\
(0.446)\end{array}$ & $\begin{array}{l}2.883 * \star \\
(0.570)\end{array}$ & $\begin{array}{l}3.117 * \star \\
(0.701)\end{array}$ & $\begin{array}{l}3.079 * \star \\
(0.696)\end{array}$ \\
\hline schn & $\begin{array}{l}0.053 * \star \\
(0.006)\end{array}$ & $\begin{array}{l}0.055 * \star \\
(0.006)\end{array}$ & $\begin{array}{l}0.056 * \star \\
(0.006)\end{array}$ & $\begin{array}{l}0.056 * * \\
(0.006)\end{array}$ & $\begin{array}{l}0.060 * * \\
(0.007)\end{array}$ & $\begin{array}{l}0.066 * * \\
(0.005)\end{array}$ \\
\hline expp & $\begin{array}{l}0.018 * * \\
(0.003)\end{array}$ & $\begin{array}{l}0.019 * \star \\
(0.003)\end{array}$ & $\begin{array}{l}0.018 * * \\
(0.003)\end{array}$ & $\begin{array}{l}0.018 * * \\
(0.003)\end{array}$ & $\begin{array}{l}0.019 * * \\
(0.003)\end{array}$ & $\begin{array}{l}0.019 * * \\
(0.003)\end{array}$ \\
\hline expp2 & $\begin{array}{l}-0.046 * \star \\
(0.005)\end{array}$ & $\begin{array}{l}-0.047 * \star \\
(0.005)\end{array}$ & $\begin{array}{l}-0.046 * \star \\
(0.005)\end{array}$ & $\begin{array}{l}-0.047 * \star \\
(0.005)\end{array}$ & $\begin{array}{l}-0.048 * \star \\
(0.006)\end{array}$ & $\begin{array}{c}-0.045 * \star \\
(0.006)\end{array}$ \\
\hline sex & $\begin{array}{l}0.271 * \star \\
(0.031)\end{array}$ & $\begin{array}{l}0.280 * \star \\
(0.031)\end{array}$ & $\begin{array}{l}0.280 * * \\
(0.031)\end{array}$ & $\begin{array}{l}0.280 * * \\
(0.031)\end{array}$ & $\begin{array}{l}0.294 * \star \\
(0.034)\end{array}$ & $\begin{array}{l}0.317 \star \star \\
(0.029)\end{array}$ \\
\hline oil & & & $\begin{array}{l}0.802 * \star \\
(0.140)\end{array}$ & $\begin{array}{l}0.771 * \star \\
(0.151)\end{array}$ & $\begin{array}{l}0.764 * \star \\
(0.153)\end{array}$ & $\begin{array}{l}0.766 * * \\
(0.153)\end{array}$ \\
\hline captlr & & & & $\begin{array}{r}-0.052 \\
(0.060)\end{array}$ & $\begin{array}{c}-0.068 \\
(0.064)\end{array}$ & $\begin{array}{c}-0.069 \\
(0.065)\end{array}$ \\
\hline Regg & & Yes & Yes & Yes & Yes & Yes \\
\hline \# obs : & 3101 & 3101 & 3101 & 3101 & 2640 & 2421 \\
\hline$R-s q$ & 0.162 & 0.202 & 0.229 & 0.229 & 0.201 & 0.193 \\
\hline
\end{tabular}

Note: Standard errors in parentheses with $\mathrm{p}<0.05=\star, \mathrm{p}<0.01=* *$. All models represent Mincerian-type regressions of log wages on individual characteristics plus the share of people with university degree in cities (insh89). Model 1 is a basic specification without additional controls. All models are estimated using OLS. Standard errors are adjusted for correlation within cities. 
Figure 1. Share of college graduates in 1989 (census data) and 1994 (RLMS estimates) by city

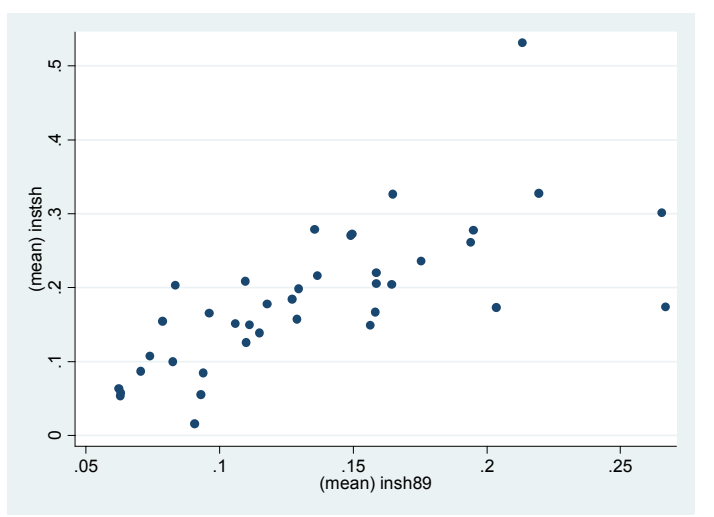

Figure 2. Share of college graduates in 1989 (census data) and the pre-transition number of institutes/universities

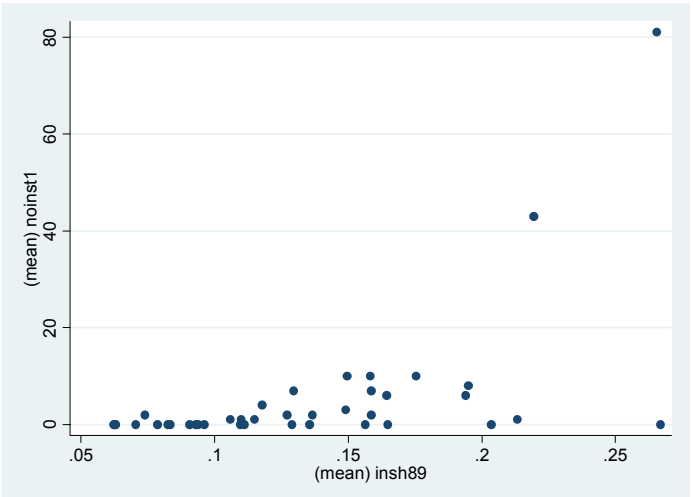

Figure 3. Share of college graduates in 1989 (census data) and the pre-transition number of institutes/universities (Moscow and St. Petersburg excluded)

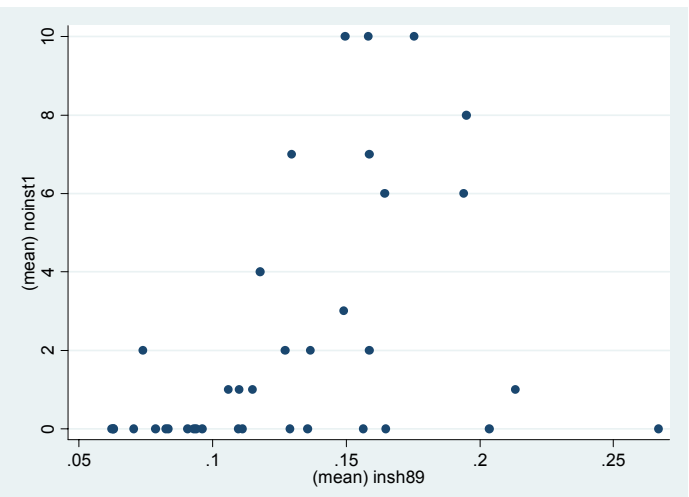


Figure 4. Population of cities in 1989 (census data) and the pre-transition number of institutes/universities

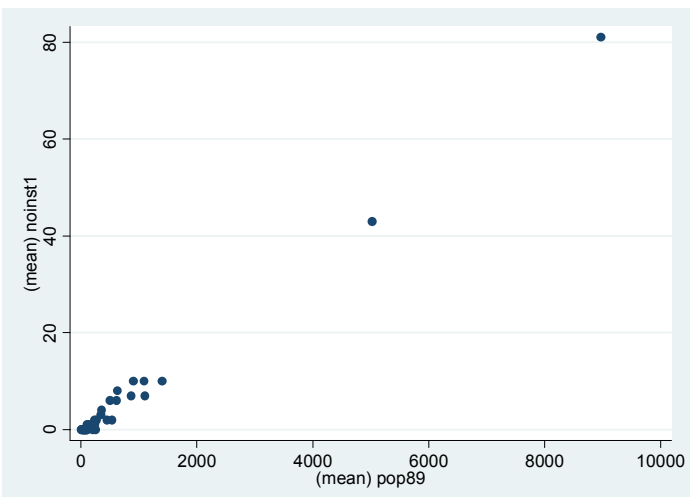

Figure 5. Population of cities in 1989 (census data) and the pre-transition number of institutes/universities (Moscow and St. Petersburg excluded)

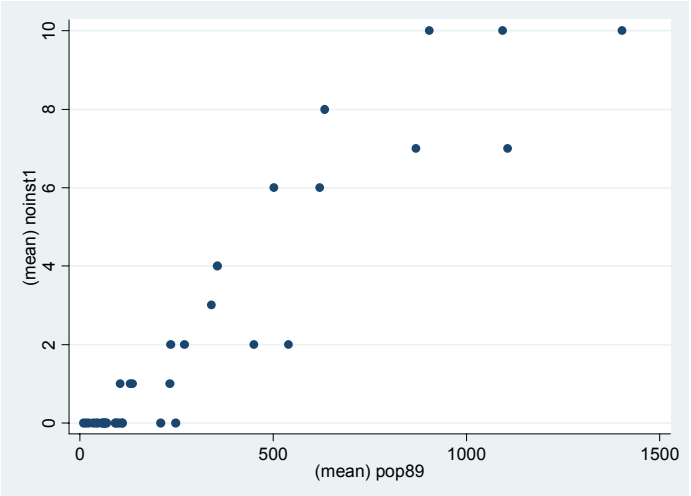




\section{Appendix 1: Definition of variables}

\section{Individual characteristics:}

wage - hourly earnings from primary and secondary jobs in the reference month. The variable refers to money actually received rather than to the contractual wage. A correction for wage arrears is applied (if a person received no wage in the reference month, the wage is approximated by the value of arrears divided by the length of the period over which these arrears had been accumulated. Outliers corresponding to $2,5 \%$ of observations in the lower and upper tails of the wage distribution are excluded from the dataset. Earnings data are recalculated into December 2001 prices.

Inwage - log hourly earnings from primary and secondary jobs in the reference month, i.e., $\log ($ wage) .

schl - individual educational attainment (years of schooling). The variable accounts for years of schooling and is imputed on the basis of highest degree obtained, in particular, 9 years for incomplete secondary education, 11 years for ordinary secondary, 12 years for vocational, 13 years for specialized secondary, 16 years for college, 19 years for a graduate degree. The procedure is borrowed from Konstantinova-Vernon (2002).

expp - working experience (potential, calculated as age minus schooling minus seven).

expp2 - working experience squared.

sex - gender, 1 refers to males.

\section{City characteristics:}

Insh02 - fraction of people with higher education in cities in 2002. Calculated for adults (15 years and older) from RLMS.

insh94 - fraction of people with higher education in cities in 1994. Calculated for adults (15 years and older) from RLMS.

insh89 - fraction of people with higher education in cities in 1989. Census data from 1989, adult population (15 years and older). 
noinst - number of higher education establishments in a city at the end of the Soviet time.

oil - dummy variable for the cities whose economies are centred around the oil extraction industry (Usinsk, Lyantor and Surgut).

captlr - dummy variable for cities which are administrative centres of the regions.

Regg1 - Regg8 - dummy variables for regions (RLMS classification: Moscow and St. Petersburg, Northern and North Western, Central and Central Black-Earth, Volga-Vaytski and Volga Basin, North Caucasian, Ural, Western Siberian, Eastern Siberian and Far Eastern).

pop89 - population of cities in thousands, 1989 census data. 